\title{
Foliar anatomy and microscopy of six Brazilian species of Baccharis (Asteraceae)
}

\author{
J. M. Budel ${ }^{1}$ \\ | V. Raman ${ }^{2}$ \\ L. M. Monteiro ${ }^{1}$ \\ V. P. Almeida ${ }^{1}$ \\ G. Heiden ${ }^{4}$ | I. J. M. Takeda5 | I. A. Khan² \\ ${ }^{1}$ Departamento de Ciências Farmacêuticas, Universidade Estadual de Ponta Grossa (UEPG), Ponta Grossa, Paraná, Brasil \\ ${ }^{2}$ National Center for Natural Products Research, School of Pharmacy, University of Mississippi, University, Mississippi \\ ${ }^{3}$ Pós-Graduação em Ciências Farmacêuticas, Universidade Federal do Paraná (UFPR), Curitiba, Paraná, Brasil \\ ${ }^{4}$ Embrapa Clima Temperado, Pelotas, RS, Brasil \\ ${ }^{5}$ Departamento de Meio Ambiente, Universidade Estadual de Maringá (UEM), Umuarama, Paraná, Brasil
}

V. B. Bobek ${ }^{3}$

\section{Correspondence}

J. M. Budel, Departamento de Ciências

Farmacêuticas, Universidade Estadual de

Ponta Grossa (UEPG), Ponta Grossa,

Paraná, Brasil.

Email: janemanfron@hotmail.com

\section{Funding information}

CAPES - Coordenação de Aperfeiçoamento de Pessoal de Nível Superior, Grant/Award Number: 88881.119611/2016-01; UEPG Universidade Estadual de Ponta Grossa and Araucaria Foundation; National Center for Natural Products Research (NCNPR), University of Mississippi for facilities and technical support

Review Editor: Prof. Alberto Diaspro

\begin{abstract}
We report for the first time the presence of cluster crystals of calcium oxalate within the glandular trichomes and oil bodies in the mesophyll for Baccharis species. Moreover, the comparative leaf anatomy and micro-morphology of six species of Baccharis, namely B. illinita, B. microdonta, B. pauciflosculosa, B. punctulata, B. reticularioides, and B. sphenophylla is investigated by light and scanning electron microscopy. The studied species exhibited differences in their leaf anatomical features such as the morphology of the cuticle, type and occurrence of the stomata, presence or absence of glandular trichomes, shape of the flagelliform trichomes, and the arrangement of the mesophyll tissues. These differences can be helpful in the species identification and classification and could represent informative characters for the reconstruction of the evolution of the genus.
\end{abstract}

KEYWORDS

Baccharis, druses, leaf anatomy, light and scanning electron microscopy, oil bodies

\section{1 | INTRODUCTION}

Baccharis L. (Asteraceae) is a New World genus comprising 435 species distributed from Argentina to USA (BFG, 2015; Müller, 2013). In Brazil, the genus is represented by about 180 species (Heiden, 2017). Several biological activities have been reported for various species of Baccharis such as antimicrobial, antibacterial, antifungal, antiprotozoal, antiviral, antioxidant, gastroprotective, antidiabetic, anti-inflammatory, immunomodulatory, antimutagenic, chemopreventive (Campos et al., 2016), and cytotoxic properties (Pereira et al., 2017).

Previous authors have reported that many Baccharis species have similar morphologies, making their morphological identification difficult (Perez \& Anesini, 2006). In this situation, anatomical studies can provide helpful information in solving taxonomic problems (Baggio, Freitas, Rieck, \& Marques, 2015, 2016; Freire, Urtubey, \& Giuliano, 2007). Furthermore, different species of Baccharis are called by the same traditional names and used indiscriminately for the same therapeutic purposes (Bobek et al., 2015). Several Baccharis species share the common names carquejas (plants with winged stems or cladodes) or vassouras (plants without winged stems) creating confusion in species identification. The confusion due to similar vernacular names is one of the main causes of misidentification of plant drugs.

A bibliographic review performed since 2003 revealed that only $30 \%$ of all species of Baccharis were investigated for their chemical or biological properties. The main constituents reported in the literature are flavonoids and terpenoid compounds. Baccharis species produce volatile oils that mainly contain sesquiterpenes and monoterpenes. Many of the medicinal properties reported for Baccharis are attributed to their volatile oils (Florão et al., 2016).

Six species of Baccharis, namely B. illinita DC., B. microdonta DC., B. pauciflosculosa DC., B. punctulata DC., B. reticularioides Deble \& A.S. Oliveira, and B. sphenophylla Dusén ex Malme are analyzed in the 
present study. Previous studies show that B. illinita has protective actions against gastric lesions of the mucosa, ability to reduce gastric acid secretion (Baggio et al., 2008), and possess antinociceptive (Freitas et al., 2009) and antioxidant activities (Brighente, Dias, Verdi, \& Pizzolatti, 2007).

Baccharis microdonta has showed antibacterial activity against Salmonella typhi (Perez \& Anesini, 1994) and anti-inflammatory activities (Soares et al., 2012). Its volatile oil has a high concentration (49.91\%) of oxygenated sesquiterpenes (Lago et al., 2008). Baccharis pauciflosculosa has showed antimicrobial activities (Perez \& Anesini, 1993, 1994). It has been reported that $B$. punctulata contains bicyclogermacrene, ciscadin-4-en-ol and (Z)-ocimene as the main components of the volatile oil (Schossler et al., 2009). There is no pharmacobotanical, pharmacological or chemical characterization studies available for $B$. reticularioides and B. sphenophylla.

Considering the confusions in the identification of different species of Baccharis due to their morphological similarities, the present research was aimed to examine and compare the leaf anatomy of six sympatric Baccharis species. The findings of the study can be used for species identification as well as quality control of herbal products.

\section{2 | MATERIAL AND METHODS}

\section{1 | Plant material}

Fresh samples of vegetative aerial parts, at least six specimens each, of Baccharis illinita, B. microdonta, B. pauciflosculosa, B. punctulata, B. reticularioides, and $B$. sphenophylla were collected from open and sunny habitats in Campos Gerais, Ponta Grossa, Paraná, Southern Brazil (coordinates $25^{\circ} 5^{\prime} 11 \mathrm{~S}$ and $50^{\circ} 6^{\prime} 23 \mathrm{~W}$ ), in March 2016. Voucher specimens of B. illinita (HUPG 10223) were deposited in the Herbarium of State University of Ponta Grossa, Brazil, while the specimens of the other five species were registered as ECT 644 (B. microdonta), ECT 641 (B. pauciflosculosa), ECT 645 (B. punctulata), ECT 642 (B. reticularioides), and ECT 647 (B. sphenophylla) and deposited in the Herbarium of Embrapa Clima Temperado (ECT) in Rio Grande do Sul, Brazil.

\section{2 | Preparation of samples for light microscopy}

The leaves were fixed in FAA 70 (formalin-acetic acid-alcohol) for 5 days and washed in distilled water. Free-hand sections were prepared using razor blades. The sections were hydrated and stained with toluidine blue (O'Brien, Feder, \& McCully, 1964). The sections were then mounted on glass slides in a drop of $50 \%$ glycerin.

For the analysis of leaf epidermal features, the leaf specimens were cleared by dipping them in sodium hypochlorite solution (household bleach) until translucent. The samples were then washed with water and stained with safranin. Photomicrographs were prepared using Nikon E600 microscope equipped with Nikon DSFiv camera systems and Nikon Elements imaging software (Nikon Inc., Tokyo, Japan).

Fluorescent microscope (Nikon E600) was used to study the fluorescent components such as oil bodies. Birefringent elements such as calcium oxalate crystals were observed using a polarized microscope
(Nikon E600 POL). Both microscopes were equipped with Nikon DSFiv camera systems and Nikon Elements imaging software (Nikon Inc., Tokyo, Japan).

\section{3 | Histochemical analyses}

Paradermal and cross-sections of fixed leaf materials were prepared using razor blades. The main classes of the secondary metabolites were investigated using the following histochemical tests: phloroglucinol/ $\mathrm{HCl}$ to identify lignified tissues (Sass, 1951); sudan III for testing the presence of lipophilic compounds (Foster, 1949); $2 \%$ solution (w/v) of ferric chloride to demonstrate phenols (Johansen, 1940); and 1\% iodine solution to test for starch (Berlyn \& Miksche, 1976).

\subsection{Scanning electron microscopy (SEM)}

For SEM analysis, samples fixed in FAA were passed through a series of ethanol solutions of increasing concentration ( $80 \%$, $90 \%$, and $100 \%)$. The dehydrated samples were then dried in a Leica EM CPD300 critical point drier (Leica Microsystems, Wetzlar, Germany) using liquid $\mathrm{CO}_{2}$. The fully dried samples were mounted on aluminum stubs with doublesided adhesive tapes and then coated with gold using a Hummer 6.2 sputter coater (Anatech USA, Union City, CA) supplied with argon gas. Photomicrographs of the specimens were prepared using a JSM-5600 SEM (JEOL Ltd., Tokyo, Japan) at the University of Mississippi.

\section{5 | Micromeasurements}

Quantitative studies of stomata were performed by taking 20 measurements from multiple leaf specimens. Stomatal index (SI) was calculated using the following formula wherein $S=$ number of stomata per unit area, and $E=$ number of epidermal cells (including trichomes) in the same unit area.

$$
S I=\frac{S}{E+S} \times 100
$$

The length and width of stomata were measured from 20 stomata at different locations on the leaf blade for each species to determine the average stomatal size. Stomata types were recognized based on the work by Van Cotthen (1970).

\section{3 | RESULTS AND DISCUSSION}

In the present work, the key features of morpho-anatomies of six species of Baccharis are investigated and compared. The main characteristics that support the differentiation are summarized in Table 1. In Baccharis species, the leaves usually have straight to slightly wavy anticlinal epidermal cell walls (Freire et al., 2007). However, sinuous anticlinal walls were reported for B. anomala DC. (Budel \& Duarte, 2008a), B. decussata (Klatt) Hieron. and B. pentlandii DC. (Freire et al., 2007) all of them belonging to Baccharis subgen. Molina (Pers.) Heering (Heiden, 2014). In the present study, the anticlinal cell walls are observed to be straight on both leaf epidermises (Figure $1 a-f, i-l$ ) in all the other species investigated that belongs to $B$. subgen. Baccharis, except to $B$. 


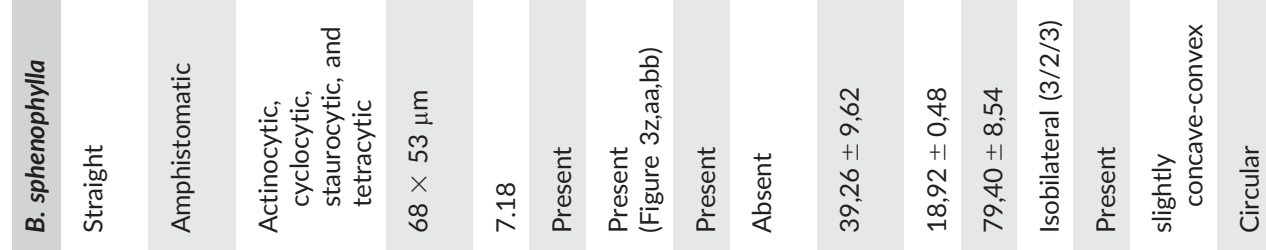

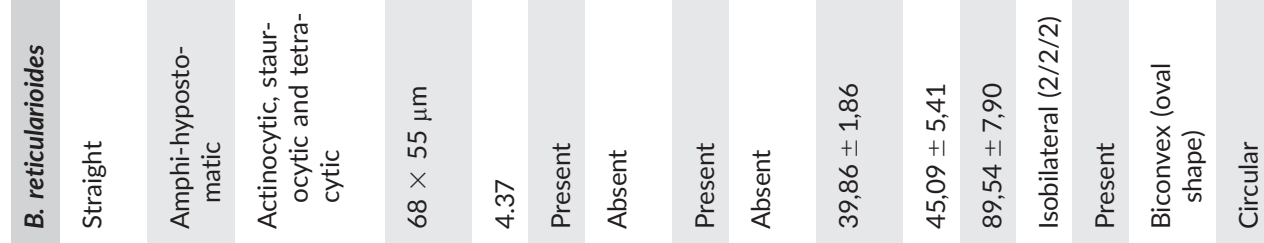

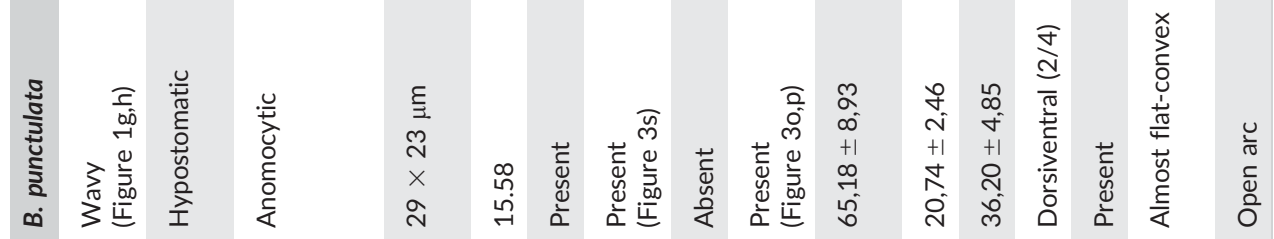

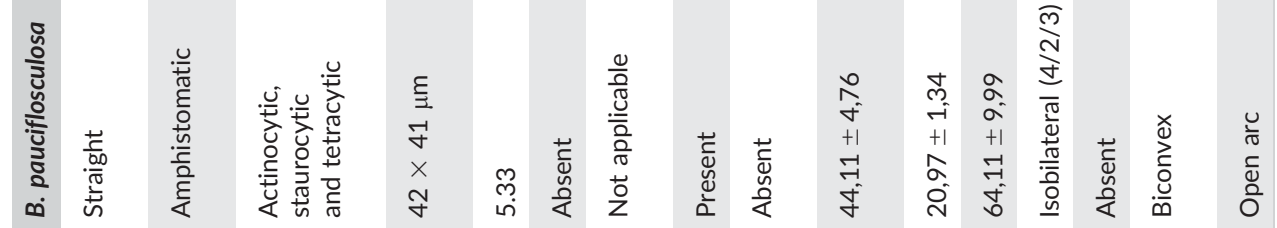

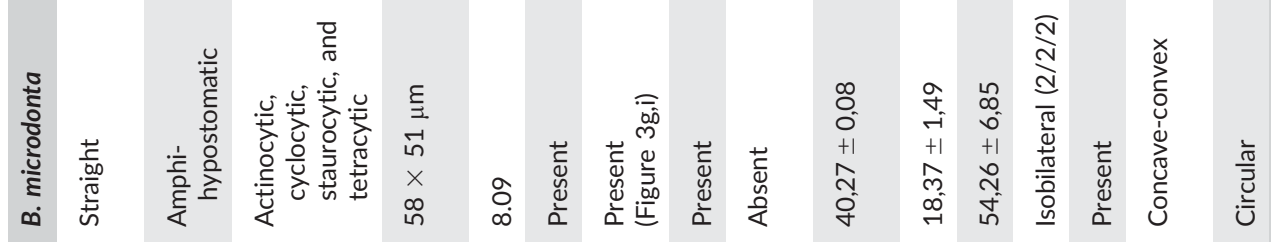

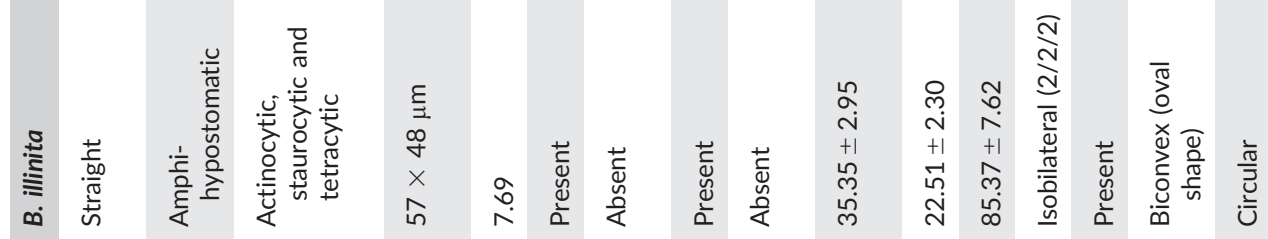

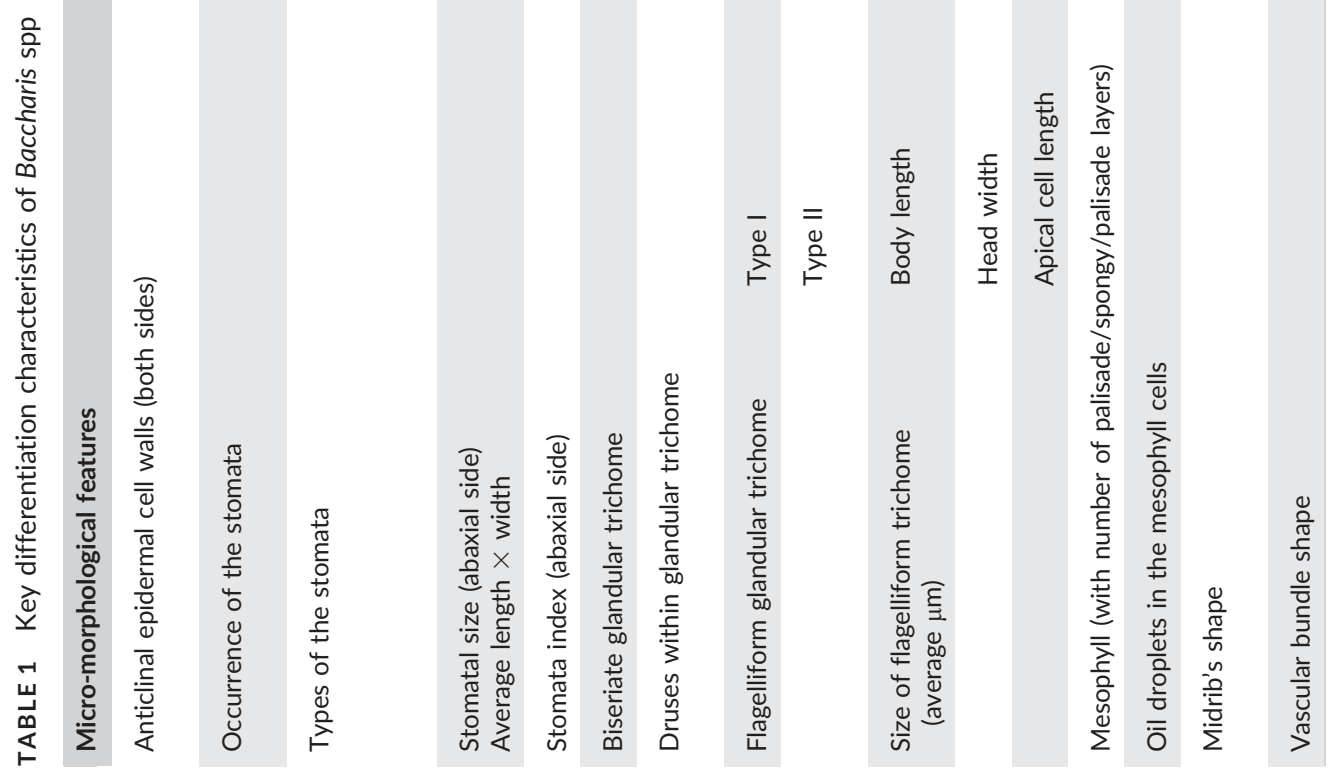



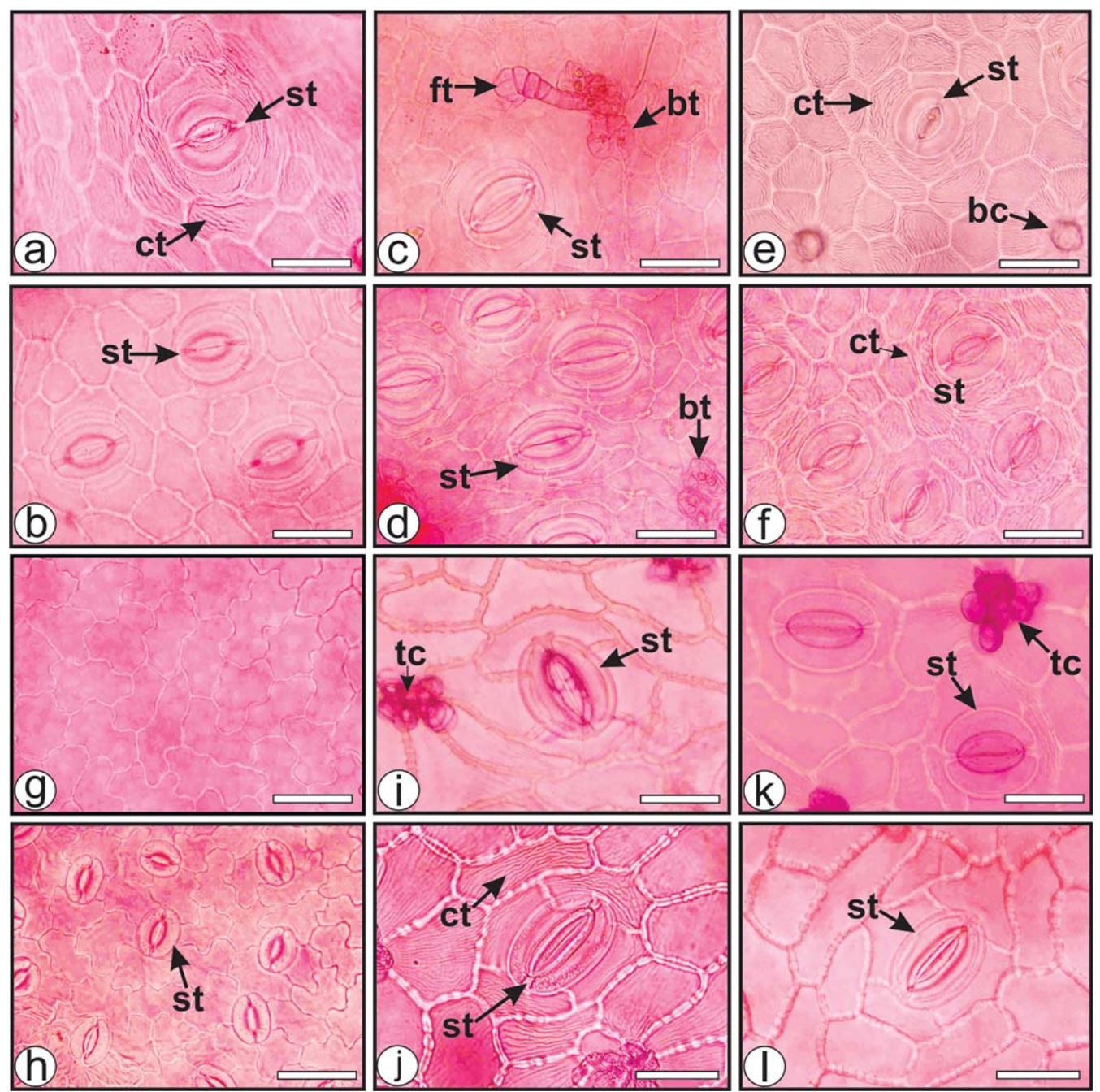

FIGURE 1 Leaf epidermis in Baccharis [Light microscopy; stained in safranin]. B. illinita (a, b), B. microdonta (c, d), B. pauciflosculosa (e, f), B. punctulata (g, h), B. reticularioides (i, j), B. sphenophylla (k, I). Adaxial side (a, c, e, g, i, k), Abaxial side (b, d, f, h, j, l). [bc, base cell of flagelliform trichome; bt, biseriate trichome; ct, cuticle; ft, flagelliform trichome; st, stomata; tc, trichomes in cluster]. Scale bar $=100 \mu \mathrm{m}$ [Color figure can be viewed at wileyonlinelibrary.com]

punctulata in which the anticlinal walls are sinuous on both sides (Figure 1g,h) and that belongs to B. subgen. Molina.

In Baccharis species, the cuticle on the leaf epidermal surfaces is usually striated (Jasinski et al., 2014; Bobek et al., 2015, 2016). All the six Baccharis species included in this study have striated cuticle on the abaxial leaf surface (Figure 2c,f,i,l,o,r). However, B. microdonta (Figure $2 \mathrm{f}$ ) and $B$. sphenophylla (Figure $2 \mathrm{r}$ ) showed cuticle striations in a perpendicular direction around trichome bases and as concentric rings around stomata. In B. punctulata, the cuticle striations are arranged in a perpendicular orientation around stomata (Figure 2l). On the adaxial side of the leaves, B. pauciflosculosa (Figure 2g,h), B. punctulata (Figure 2j,k) and B. reticularioides (Figure $2 \mathrm{~m}, \mathrm{n}$ ) show striated cuticle; B. illinita (Figure $1 \mathrm{a}, \mathrm{b}$ ) and $B$. sphenophylla (Figure $2 \mathrm{p}, \mathrm{q}$ ) present slightly striated cuticle, showing concentric rings around stomata (Figure 2b,p) and radiating at the bases of trichomes (Figure 2a,q). Only B. microdonta shows smooth cuticle (Figure 2e), yet striated around the stomata (Figure $2 \mathrm{~d}$ ) and radiating around the trichome bases (Figure 2e).
Freire et al. (2007) analyzed 38 species of Baccharis and observed six different types of stomata, such as anomocytic in B. microcephala (Less.) DC., anisocytic in B. trimera (Less.) DC., cyclocytic in B. articulata (Lam.) Pers., actinocytic in B. pilularis DC., tetracytic in B. salicifolia (Ruiz \& Pav.) Pers., and staurocytic in B. conferta Kunth. The leaves of a majority of these species were of amphistomatic type i.e. having stomata on both adaxial and abaxial epidermises.

In the current study, actinocytic (Figure 1b,d,f), staurocytic (Figure 1d,f), and tetracytic (Figure 1a,b,e,i,j,k,l) stomata were observed to be the most common types of stomata (Table 1). In addition, anomocytic (Figure 1h) and cyclocytic (Figure 1c) types were also observed. Baccharis punctulata can be distinguished from other species by its anomocytic type of stomata (Figure $1 \mathrm{~h}$ ).

Considering the occurrence of stomata in the leaves, only Baccharis punctulata is hypostomatic, i.e., having stomata only on the lower epidermis. Baccharis pauciflosculosa and B. sphenophylla are amphistomatic, and the other species are amphi-hypostomatic. Amphistomatic 

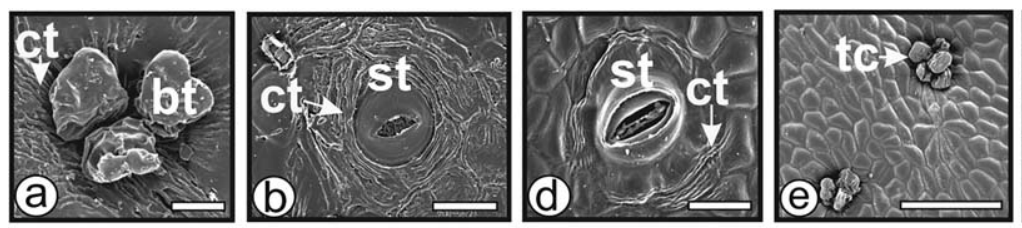

RESEARCH \&TECHNIQUE
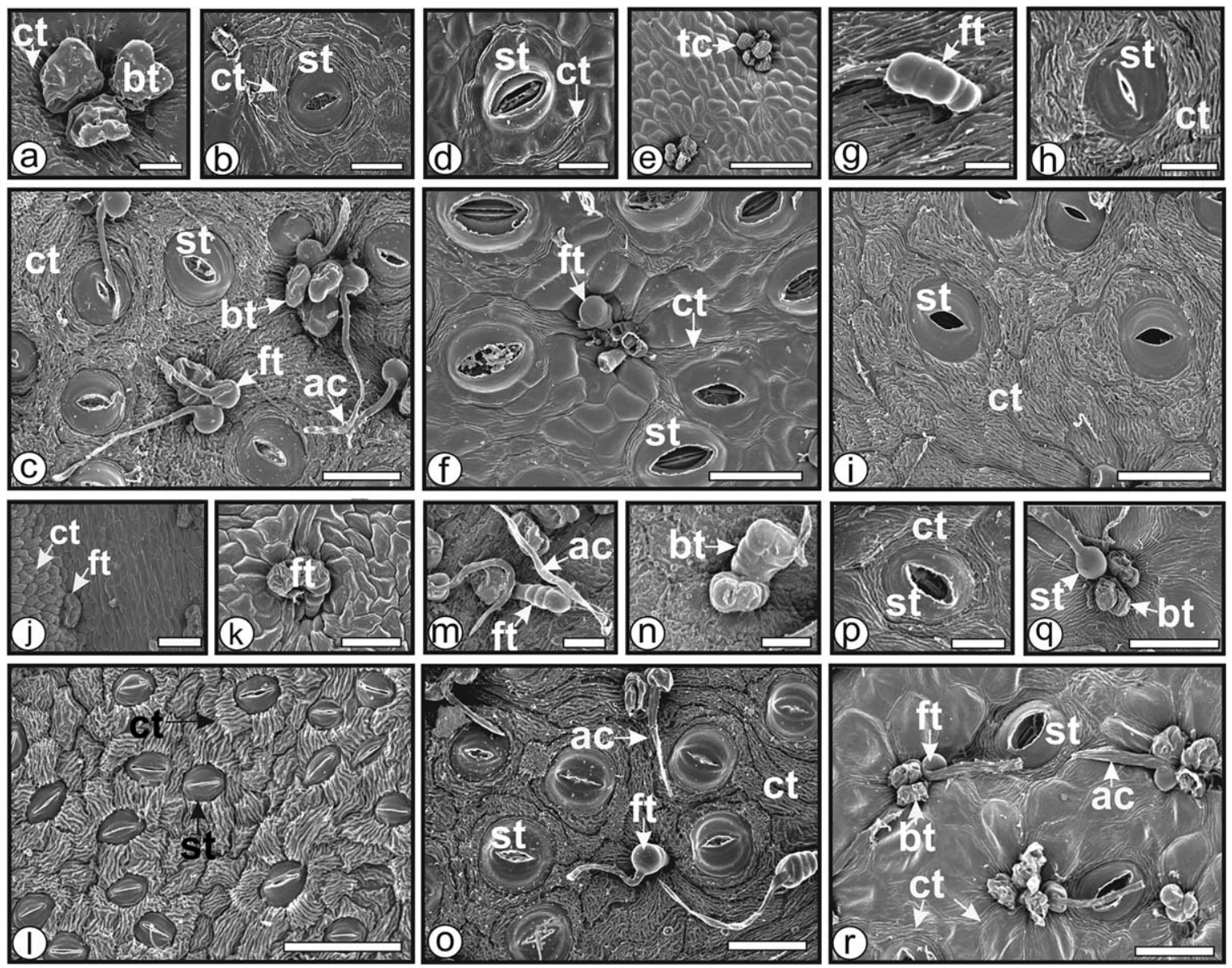

FIGURE 2 Leaf epidermis in Baccharis [Scanning electron microscopy]. B. illinita (a-c), B. microdonta (d-f), B. pauciflosculosa (g-i), B. punctulata (j-l), B. reticularioides ( $m-0)$, and B. sphenophylla (p-r). Adaxial side (a, b, d, e, g, h, j, k, m, n, p, q), abaxial side (c, f, i, I, o, r). [ac, apical cell; bt, biseriate trichome; ct, cuticle; ft, flagelliform trichome; st, stomata; tc, trichomes in cluster]. Scale bar $=d, g, h, k, m, n, p=25$ $\mu \mathrm{m} ; \mathrm{a}, \mathrm{b}, \mathrm{c}, \mathrm{f}, \mathrm{i}, \mathrm{j}, \mathrm{I}, \mathrm{o}, \mathrm{q}, \mathrm{r}=50 \mu \mathrm{m} ; \mathrm{e}=100 \mu \mathrm{m}$

leaves are frequent in Baccharis (Bobek et al., 2015, 2016; Jasinski et al., 2014). However, hypostomatic leaves were also reported for $B$. anomala (Budel \& Duarte, 2008a), B. uncinella DC. (Budel \& Duarte, 2008b), B. singularis (Vell.) G.M.Barroso (Souza et al., 2011), B. ochracea Spreng. (Barreto et al., 2015), and B. erioclada DC. (Bobek et al., 2015).

Quantitative microscopic features are useful not only for identifying different species in a genus, but also for determination of authenticity of the plant (Sheikh et al., 2016). Rodriguez, Gattuso, and Gattuso (2013) have affirmed that the stomatal size and stomatal index can contribute to differentiate different Baccharis species. Freire et al. (2007) have found that a majority of Baccharis species had stomata between 20 and $60 \mu \mathrm{m}$ long and that B. illinita can readily be distinguished from the others due to its larger stomata size (75-105 $\mu \mathrm{m}$ long), conforming to the results of the present study.

Micro-measurements of stomata (Table 1 ) revealed that the smallest stomata were present in B. punctulata $(29 \mu \mathrm{m}$ in length and $23 \mu \mathrm{m}$ in width) among the studied six species. The largest stomata were observed in B. reticularioides $(68 \times 55 \mu \mathrm{m})$ and B. sphenophylla $(68 \times$ $53 \mu \mathrm{m})$. In the case of stomatal index, B. punctulata had the highest average number of stomata (15.58) per unit area while B. reticularioides had the least number of stomata (4.37) per unit area.
Trichomes are considered the most important anatomical markers for the diagnosis of species in Baccharis. Other features, such as stomata type and epidermal cell walls can help in the differentiation as secondary characteristics (Freire et al., 2007). Two major groups of indumentum were reported in the genus, one consisting of isolated trichomes and the other with trichomes in clusters. Seven types of trichomes were reported from a study of 38 species of Baccharis (Freire et al., 2007).

Flagelliform and biseriate glandular trichomes have been frequently reported in Baccharis (Barreto et al., 2015; Bobek et al., 2015, 2016; Budel et al., 2015; Budel and Duarte, 2008a,b; Budel et al., 2012; Freire et al., 2007; Jasinski et al., 2014; Pereira et al., 2014; Rodriguez et al., 2013; Souza et al., 2011; Tischer et al., 2017).

Biseriate glandular trichomes are evidenced in the present study (Figures 2a,c,n,r and 3c,d,e,f,g,i,o-s,w,z,aa,bb) in all species except $B$. pauciflosculosa. They consist of two pairs of basal cells and a head with up to four pairs of secretory cells (Figure 3c). In the histochemical test using sudan III, the presence of the oil content was confirmed (Figure $3 c, r, w)$. These trichomes occur singly (Figure $3 c$ ), in groups with similar trichomes (Figures 2a,e,n and $3 \mathrm{w}$ ), or in groups with flagelliform trichomes (Figures 2c,f,m,q,r and 3u). 


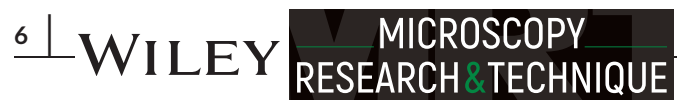
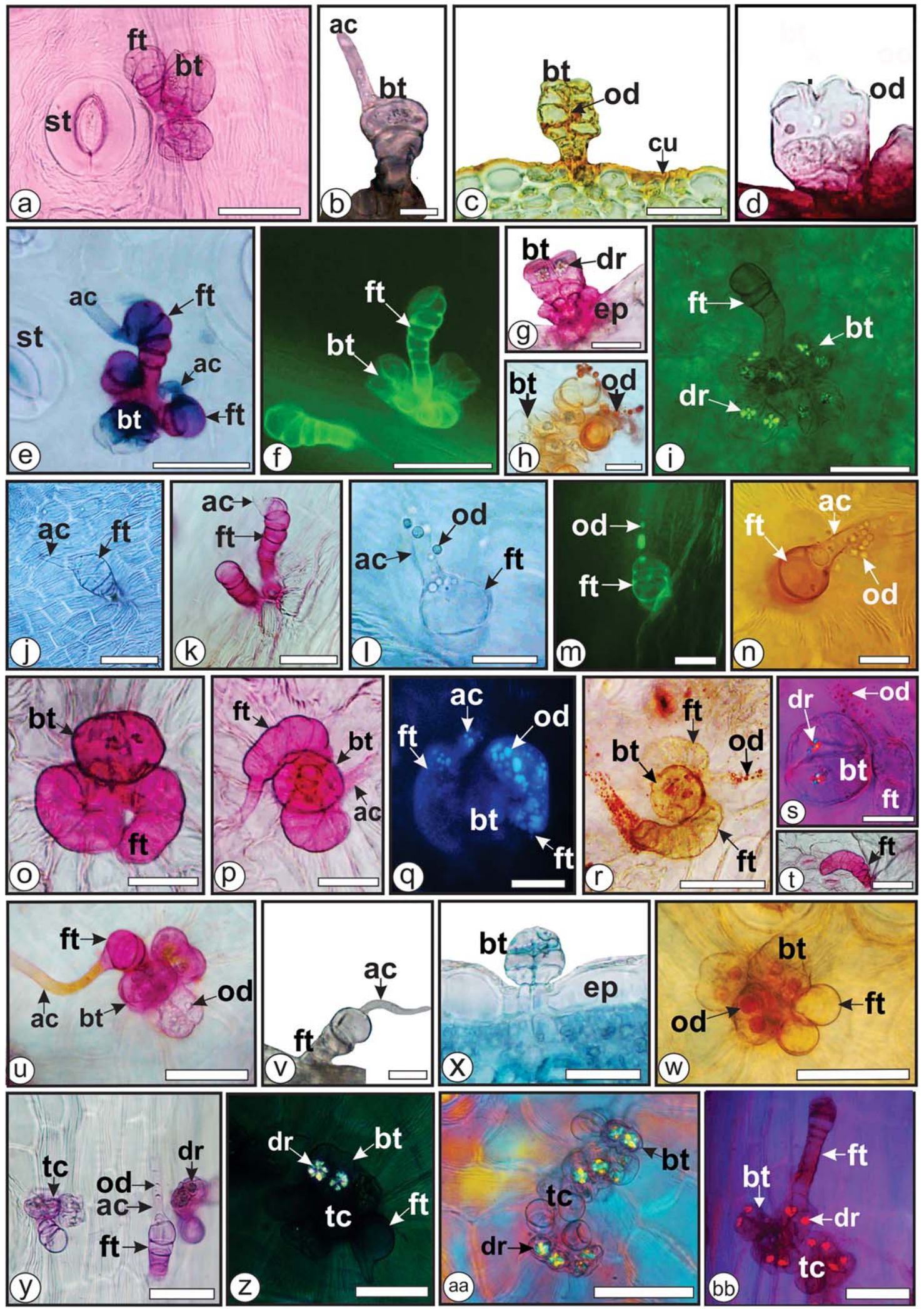

FIGURE 3 Trichomes in Baccharis species [Fluorescent (d, f, m, n, q); Polarized (i, s, z, aa, bb); and normal light (all others) microscopy; a, b, d-g, i, k, m, n, o-q, s, t, u, v, y, aa, bb- stained in safranin; c, r, w, x- treated with Sudan III to stain lipophilic/oil content; e, j, I, w, z- stained in toluidine blue]. B. illinita (a-d), B. microdonta (e-i), B. pauciflosculosa (j-n), B. punctulata (ot), B. reticularioides (u-x), B. sphenophylla (y-bb). [bt, biseriate trichome; ct, cuticle; dr, druses; ep, epidermis; ft, flagelliform trichome; od, oil droplets; st, stomata; tc, trichomes in cluster]. Scale bar $=\mathrm{b}, \mathrm{u}, \mathrm{v}=12.5 \mu \mathrm{m} ; \mathrm{c}, \mathrm{d}, \mathrm{g}, \mathrm{i}, \mathrm{k}, \mathrm{m}-\mathrm{q}, \mathrm{s}, \mathrm{w}=25 \mu \mathrm{m} ; \mathrm{a}, \mathrm{e}, \mathrm{f}, \mathrm{h}, \mathrm{j}, \mathrm{I}, \mathrm{r}, \mathrm{t}, \mathrm{x}, \mathrm{y}$-bb $=50 \mu \mathrm{m}$ [Color figure can be viewed at wileyonlinelibrary.com] 
$A$ variation in the biseriate glandular trichome was observed in $B$. microdonta, B. punctulata and B. sphenophylla. In these species, druse crystals were found within the secretory head cells of the glandular trichomes (Figure 3e,g,i,s,z,aa,bb). In B. punctulata, druses are very small and can be observed only in higher magnification (Figure 3s). According to the previous reports, only styloid, prismatic and sand types of crystals were found in the perimedullary region of the stems in Baccharis (Budel et al., 2015; Jasinski et al., 2014). Druse crystals have not been previously reported for Baccharis hence the present work forms a new report. Also, the presence of druse crystals within glandular trichomes in Baccharis is reported here for the first time. The occurrence of druses in glandular trichomes were previously mentioned in some members of the family Asteraceae including Helianthus annuus L., $\mathrm{H}$. tuberosus L. (Meric \& Dane, 2004) and Sigesbeckia jorullensis Kunth (Heinrich et al., 2002).

Biseriate glandular trichomes containing druses were observed as solitary, in groups of 2-10 as in B. microdonta and B. sphenophylla (Figure 3z,aa), or among flagelliform trichomes (Figure 3e,f,h,i,bb). In $B$. punctulata, the glandular trichomes almost always occur between a pair of flagelliform trichomes (Figure 3o-s).

In most of the previous papers, flagelliform type trichomes have been considered nonglandular probably due to the morphology of the apical cell, which usually tapered above into a long translucent tube (Barreto et al., 2015; Bobek et al., 2015, 2016; Budel \& Duarte, 2008a, b; Budel et al., 2015; Pereira et al., 2014; Souza et al., 2011). Jasinski et al. (2014) have also classified those trichomes as nonglandular in $B$. glaziovii Baker. However, they have demonstrated that the basal cells stained for lipophilic compounds, and they suggested that the flagelliform trichomes are of mixed type owing to their functional properties for protection and secretion. During the present study, oil or secretory substances were observed visually under microscope and also confirmed by histochemical tests, in body, head cells as well as the tubular apical cells of the flagelliform trichomes. For this reason, the flagelliform trichomes in the studied species are classified as "Flagelliform glandular trichomes" in the present work.

Flagelliform glandular trichomes are found in all Baccharis species included in this study (Figures 2c,f,g,k,m,o,q,r and 3b,e,f,h-n,o-r,t-v,x, $y, b b)$. Two forms of flagelliform glandular trichomes are observed and reported here for the first time. They are Type I (with straight body) and Type II (with C-shaped curved body). The body in these trichomes is secretory, voluminous, and made up to 4-9 rectangular cells. The apical cell is whip-like, tubular, translucent, containing dense oil substances (Figure $3 b, e, f, i-o, v, x, y, b b$ ) that react positively with sudan III (Figure $3 r$ ) and is also evidenced by fluorescent microscopy (Figure 3q).

Type I flagelliform glandular trichomes with erect body (sometimes slightly curved apically) are found on both sides of $B$. illinita leaves (Figures $2 \mathrm{c}$ and $3 \mathrm{~b}$ ), usually seen in clusters with biseriate glandular trichomes (Figure 3a) or rarely solitary. This type is also met in B. microdonta and frequently in cluster with biseriate glandular trichomes (Figures $2 \mathrm{f}$ and $3 \mathrm{e}, \mathrm{f}, \mathrm{i})$. Baccharis pauciflosculosa (Figures $2 \mathrm{~g}$ and $3 \mathbf{j}-\mathrm{n}$ ) shows this type of trichome on both surfaces, isolated or in clusters with up to four flagelliform or with biseriate glandular trichomes.
Baccharis reticularioides (Figures $2 \mathrm{~m}$ and $3 \mathrm{u}, \mathrm{v}, \mathrm{x}$ ) shows flagelliform glandular trichomes with straight body on both sides, commonly with biseriate glandular trichomes (devoid of druses) or in cluster with flagelliform and biseriate glandular trichomes; rarely found in solitary. Baccharis sphenophylla (Figures 2q,r and 3y,bb) also presents the same type on both sides, usually with biseriate glandular trichomes (contain druses) or in cluster with flagelliform and biseriate glandular together (rarely isolated).

Type II flagelliform glandular trichomes with curved (C-shaped) body are found on the abaxial side of B. punctulata, appearing in cluster with similar trichome and with a biseriate glandular trichome between them (Figure 3o,p). On adaxial side, they can be seen isolated (Figures $2 k$ and $3 t$ ) or with other trichome of the same type. The type and occurrence of the various types of trichomes can help in the identification and differentiation of Baccharis species.

Considering the leaf blade and comparing to the six species in cross-section, the epidermis is one-layered (Figures $3 c$ and $4 a-e, g-n, q$ ), covered by moderately thick cuticle (Figure $4 \mathrm{~b}-\mathrm{e}, \mathrm{i}, \mathrm{k}, \mathrm{n}, \mathrm{p}, \mathrm{q}$ ) that reacted positively with sudan III.

Regarding the mesophyll, only B. punctulata shows dorsiventral organization (Figure 4j,k,l), comprising two layers of palisade and about four layers of spongy parenchyma. The other species have isobilateral mesophyll formed by 2-4 layers of palisade and two layers of spongy parenchyma (Figure 4a,b,d,g,h,m,o,p). Isobilateral mesophyll has been reported for several species of Baccharis (Barreto et al., 2015; Bobek et al., 2015, 2016; Budel \& Duarte, 2010). However, dorsiventral mesophyll was observed in B. anomala (Budel \& Duarte, 2008a) and B. singularis (Souza et al., 2011).

Lersten et al., (2006) have analyzed 113 families of Angiosperms including 44 taxa from the family Asteraceae (63.6\%) and reported the presence of oil bodies in the leaf mesophyll. This characteristic is present in B. illinita (Figure 4b), B. microdonta (Figure 4d-f), B. punctulata (Figure 4k), B. reticularioides (Figure 4n,o), and B. sphenophylla (Figure $4 p, q)$. Only B. pauciflosculosa does not have this feature (Figure $4 g, h, i)$. Oil bodies in the leaf mesophyll have not been previously reported for Baccharis.

In the present study, oil bodies were detected typically in palisade parenchyma cells and in some spongy parenchyma cells. They are absent in the epidermal cells or in the vascular bundles. The oil bodies are variable in size, appear one per cell and react with sudan III (Figure 4b,e,k,n,q). In Asteraceae, solitary oil bodies were observed in Ambrosia psilostachya DC. and Erigeron annuus (L.) Pers. Even though multiple oil bodies per cell are less frequent, Cirsium vulgare (Savi) Ten. showed palisade cells containing several oil bodies (at least 10), called clustered oil bodies (Lersten et al., 2006).

Collateral vascular bundles traverse the spongy parenchyma and are encircled by a parenchymatous sheath accompanied by large secretory ducts (Figure $4 \mathrm{a}, \mathrm{f}-\mathrm{h}, \mathrm{j}, \mathrm{I}, \mathrm{m}, \mathrm{o}, \mathrm{r}$ ). These ducts have uniseriate epithelium of 6-10 cells containing dense cytoplasm and lipophilic contents in all studied species (Figure 4g,h,l,m,o,r). The presence of lipophilic content was confirmed by the orange-red staining with the addition of Sudan III (Figure 40).

Secretory ducts with these characteristics occur in numerous species of Baccharis (Bobek et al., 2015, 2016; Budel et al., 2012). It has 

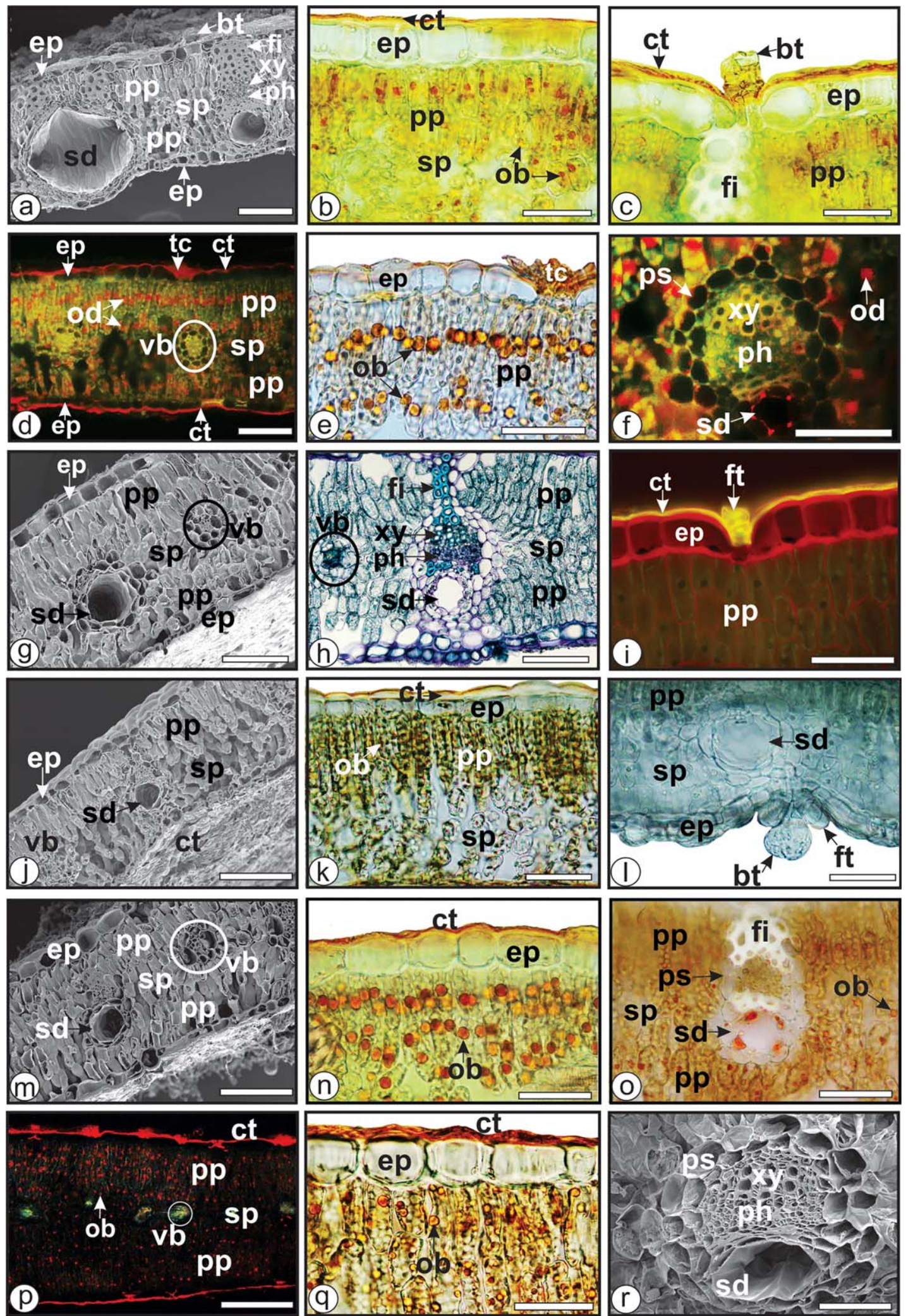

FIGURE 4 Anatomy of Baccharis - Leaf blade in cross-section [Fluorescent (d, f, i, p); Scanning electron microscopy (a, g, j, m, r); and normal light (all others) microscopy; b-f, i, k, n, o, p, q- treated with Sudan III to stain lipophilic/oil content; h, I- stained in toluidine blue]. B. illinita (a-c), B. microdonta (d-f), B. pauciflosculosa (g-i), B. punctulata (j-l), B. reticularioides (m-o), B. sphenophylla (p-r). [bt, biseriate trichome; ct, cuticle; ep, epidermis; fi, fibers; ft, flagelliform trichomes; ob, oil bodies; ph, phloem; pp, palisade parenchyma; ps, parenchymatic sheath; sd, secretory ducts; sp, spongy parenchyma; tc, trichomes in cluster; vb, vascular bundle; xy, xylem]. Scale bar = b, c, f, i, k, l, n, o, q, r = 50 $\mu \mathrm{m} ; \mathrm{a}, \mathrm{e}, \mathrm{g}, \mathrm{h}, \mathrm{j}, \mathrm{m}, \mathrm{p}=100 \mu \mathrm{m}$ [Color figure can be viewed at wileyonlinelibrary.com] 

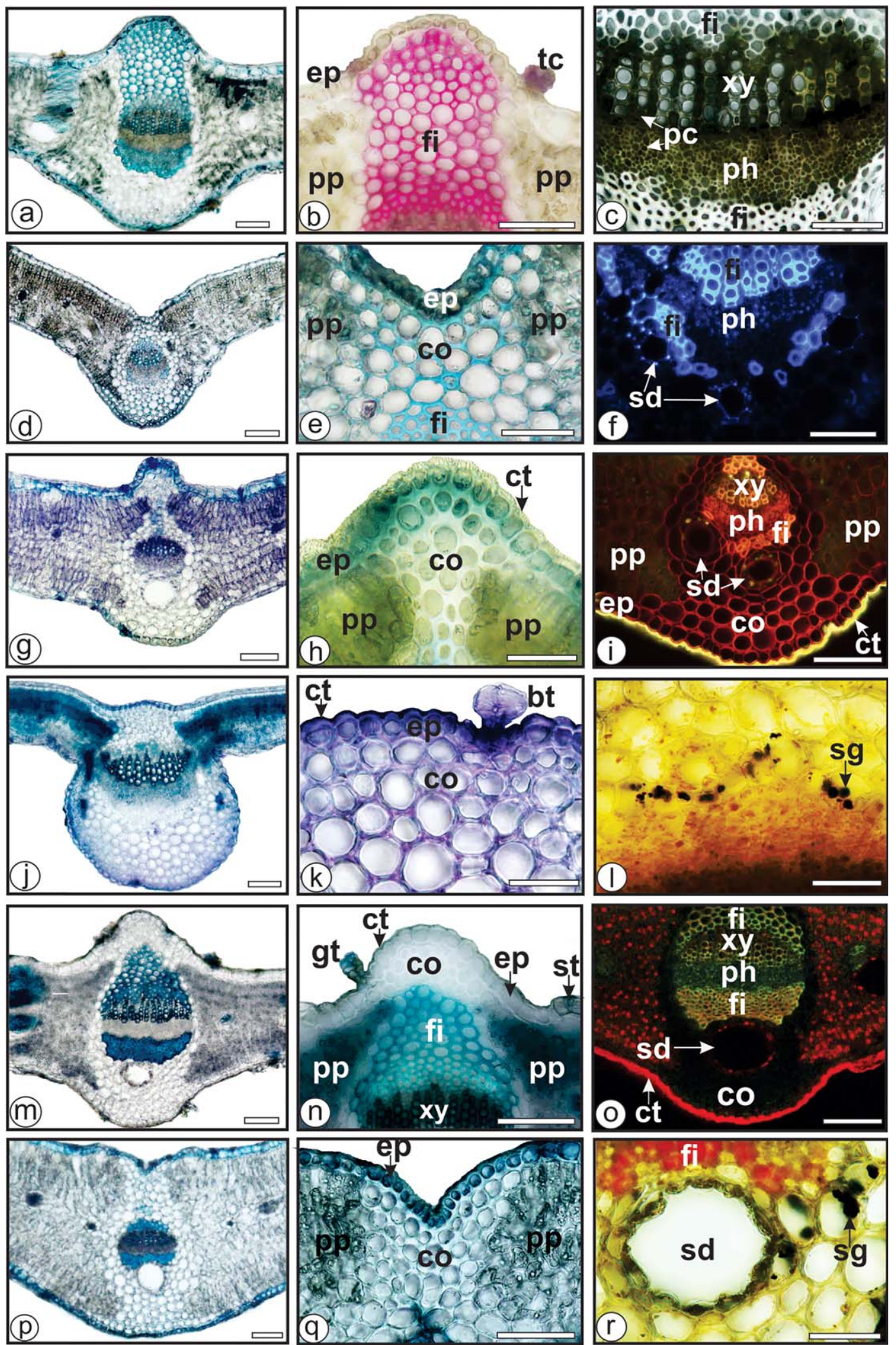

FIGURE 5 Anatomy of Baccharis - Midrib in cross-section [Fluorescent ( $\mathrm{f}, \mathrm{i}, \mathrm{o}$ ) and normal light (all others) microscopy; b- stained in safranin; c- treated with ferric chloride to react with phenolic compounds; i, r- treated with iodine solution to react with starch grains; a, $d-k$, m, $\mathrm{n}, \mathrm{p}, \mathrm{q}$ - stained in toluidine blue; o- treated with Sudan III to stain lipophilic/oil content]. B. illinita (a-c), B. microdonta (d-f), B. pauciflosculosa (g-i), B. punctulata (j-l), B. reticularioides (m-o), B. sphenophylla (p-r). [bt, biseriate trichome; co, collenchyma; ct, cuticle; ep, epidermis; fi, fibers; ft, flagelliform trichome; ob, oil bodies; pc, phenolic compounds; ph, phloem; pp, palisade parenchyma; ps, parenchymatic sheath; sd, secretory duct; sg, starch grains; sp, spongy parenchyma; st, stomata; tc, trichomes in cluster; xy, xylem]. Scale bar = b, c, e, f, h, i, k, l, n, o, $\mathrm{q}, \mathrm{r}=50 \mu \mathrm{m} ; \mathrm{a}, \mathrm{d}, \mathrm{g}, \mathrm{j}, \mathrm{m}, \mathrm{p}=100 \mu \mathrm{m}$ [Color figure can be viewed at wileyonlinelibrary.com] 
been demonstrated that the volatile oils that are present in the glandular trichomes and secretory ducts have biological activities (Campos et al., 2016; Florão et al., 2012; Pereira et al., 2017). According to Pagni and Masini (1999), in several members of Asteraceae family, the ducts are typically associated to the endodermis, are next to the phloem, and the secretory structures are related with the conducting system. These features are found in all studied Baccharis species.

The midrib in cross-section shows different shapes in the present study. In B. illinita (Figure 5a) and B. reticularioides (Figure 5m), the midrib is biconvex and forming an ovate shape. Baccharis pauciflosculosa (Figure 5g) also shows biconvex shape, but with a rounded projection on the adaxial side. Baccharis microdonta (Figure $5 \mathrm{~d}$ ) have concaveconvex shape, B. sphenophylla (Figure $5 p$ ) is slightly concave-convex, while B. punctulata is almost flat-convex. These characteristics can help in the differentiation of Baccharis species.

The uniseriate epidermis is coated with a layer of striated cuticle that reacted with sudan III (Figure $5 \mathrm{i}, \mathrm{O}$ ). The chlorenchyma is interrupted and substituted by some layers of angular collenchyma in B. microdonta (Figure 5e), B. pauciflosculosa (Figure 5h), B. punctulata (Figure 5k), B. reticularioides (Figure $5 n$ ) and B. sphenophylla (Figure $5 p$ ) on both sides. On the other hand, only B. illinita presents a well-developed sclerenchyma in place of the collenchyma on adaxial side. The lignification is well evidenced with phloroglucinol/ $\mathrm{HCl}$ as seen in Figure $5 \mathrm{~b}$.

A single vascular bundle, collateral and circular in shape, is present in B. illinita (Figure 5a), B. microdonta (Figure 5d), B. reticularioides (Figure $5 \mathrm{~m}$ ) and in B. sphenophylla (Figure $5 \mathrm{p}$ ). Baccharis pauciflosculosa (Figure $5 \mathrm{~g}$ ) and B. punctulata (Figure 5j) show a single collateral vascular bundle in open arc.

In all the six studied species, the vascular bundle is embedded in the ground parenchyma with lignified perivascular fibers abutting the xylem and phloem (Figure 5b,f). Phenolic compounds, in reaction with ferric chloride, are found in xylem and phloem as observed in Figure $5 c$. Vascular bundle is surrounded by a parenchymatous sheath that contains starch grains which reacted with $1 \%$ iodine solution in the histochemical tests (Figure 5i,r). Starch grains are small and rounded and found in aggregates of two or more granules (Figure 5l,r). The parenchymatic sheath is in association with secretory ducts (1-3) adjoining the phloem. These secretory ducts show an epithelium formed by a layer of 4-20 cells (Figure 5f,i,o,r). Phenolic compounds are found in the phloem and xylem in all Baccharis species as shown in Figure $5 \mathrm{c}$.

\section{4 | CONCLUSION}

In the present work, a detailed leaf anatomy of six species of Baccharis is presented and compared. Although the basic anatomies of these species are more or less similar, they also show distinctive differences in some features that can be used as markers for species identification. For example, the leaf epidermal cells in B. punctulata have wavy anticlinal walls while all the other five species have straight walls. This species can also be distinguished from others by its hypostomatic leaves with anomocytic stomata. None of the other five species have this type of stomata. The average stomatal index is very high (15.58) in B. punctulata whereas it ranges from 4.37 to 8.09 in the other five species. Biseriate glandular trichomes are present in all species except $B$. pauciflosculosa. Calcium oxalate druses are found within the biseriate glandular trichomes in B. microdonta, B. punctulata, and B. sphenophylla whereas they are not observed in the other species. The leaves in $B$. punctulata are dorsiventral while they are isobilateral in the other five species. Thus, the anatomical and micromorphological features of the leaves can help in the differentiation of Baccharis species included in this study. Similar studies are required for other species to develop a more reliable and complete taxonomic classification of the genus.

\section{ACKNOWLEDGMENTS}

JMB are grateful to CAPES - Coordenação de Aperfeiçoamento de Pessoal de Nível Superior (88881.119611/2016-01), UEPG - Universidade Estadual de Ponta Grossa and Araucaria Foundation for financial support and a fellowship as well as to National Center for Natural Products Research (NCNPR), University of Mississippi for facilities and technical support.

\section{ORCID}

J. M. Budel (D) http://orcid.org/0000-0003-1873-2253

\section{REFERENCES}

Heiden, G. Baccharis in Flora do Brasil 2020 em construção (2017). Jardim Botânico do Rio de Janeiro. Retrieved from http://floradobrasil. jbrj.gov.br/reflora/floradobrasil/FB5151

Baggio, C. H., Freitas, C. S., Rieck, L., \& Marques, M. C. A. (2003). Gastroprotective effects of a crude extract of Baccharis illinita DC. in rats. Pharmacological Research, 47, 93-98.

Barreto, I. F., Paula, J. P., Farago, P. V., Duarte, M. R., \& Budel, J. M. (2015). Pharmacobotanical study of leaves and stems of Baccharis ochracea Spreng. for quality control. Latin American Journal of Pharmacy, 34, 1497-1502.

Berlyn, G. P., \& Miksche, J. P. (1976). Botanical microtechnique and cytochemistry. Ames, lowa: lowa State University Press.

Bobek, V. B., Almeida, V. P., Pereira, C. B., Heiden, G., Duarte, M. R., Budel, J. M., \& Nakashima, T. (2015). Comparative pharmacobotanical analysis of Baccharis caprariifolia DC. and B. erioclada DC. from Campos Gerais, Paraná, Southern of Brazil. Latin American Journal of Pharmacy, 34, 1396-1402.

Bobek, V. B., Heiden, G., Oliveira, C. F., Almeida, V. P., Paula, J. P., Farago, P. V., ... Budel, J. M. (2016). Comparative analytical micrographs of vassouras (Baccharis, Asteraceae). Revista Brasileira de Farmacognosia, 26(6), 665-672.

BFG - ... The Braziliab Flora Group. (2015). Growing knowledge: an overview of seed plant diversity in Brazil. Rodriguésia, 66, 10851113.

Brighente, I. M. C., Dias, M., Verdi, L. G., \& Pizzolatti, M. G. (2007). Antioxidant activity and total phenolic content of some Brazilian species. Pharmaceutical Biology, 45(2), 156-161.

Budel, J. M., \& Duarte, M. R. (2008a). Estudo farmacobotânico de partes vegetativas aéreas de Baccharis anomala DC., Asteraceae. Revista Brasileira De Farmacognosia, 18, 761-768.

Budel, J. M., \& Duarte, M. R. (2008b). Estudo farmacobotânico de folha e caule de Baccharis uncinella DC, Asteraceae. Latin American Journal of Pharmacy, 27, 740-746. 
Budel, J. M., \& Duarte, M. R. (2010). Macro and microscopic characters of the aerial vegetative organs of Carqueja: Baccharis usterii Heering Brazilian Archives of Biology and Technology, 53(1), 123-131.

Budel, J. M., Duarte, M. R., Döll-Boscardin, P. M., Farago, P. V., Matzenbacher, N. I., Sartoratto, A., \& Maia, B. H. L. N. S. (2012). Composition of essential oils and secretory structures of Baccharis anomala, B. megapotamica and B. ochracea. Journal of Essential Oil Research, 24(1), 19-24

Budel, J. M., Paula, J. P., Santos, V. L. P., Franco, C. R. C., Farago, P. V., \& Duarte, M. R. (2015). Pharmacobotanical study of Baccharis pentaptera. Revista Brasileira de Farmacognosia, 25, 314-319.

Florão, A., Budel, J. M., Duarte, M. R., Marcondes, A., Rodrigues, R. A. F., Rodrigues, M. V. N., ... Weffort-Santos, A. M. (2012). Essential oils from Baccharis species (Asteraceae) have anti-inflammatory effects for human cells. Journal of Essential Oil Research, 24(6), 561-570.

Foster, A. S. (1949). Practical plant anatomy (2nd ed.). New Jersey, Princeton: D. Van Nostrand.

Freire, S. E., Urtubey, E., \& Giuliano, D. A. (2007). Epidermal characters of Baccharis (Asteraceae) species used in traditional medicine. Caldasia, 29, 23-38.

Freitas, C. S., Baggio, C. H., Dos Santos, A. C., Mayer, B., Twardowschy, A., Luiz, A. P., ... Santos, A. R. (2009). Antinociceptive properties of the hydroalcoholic extract, fractions and compounds obtained from the aerial parts of Baccharis illinita DC. in Mice. Basic \& Clinical Pharmacology \& Toxicology, 104(4), 285-292.

Freitas, C. S., Baggio, C. H., Finau, J., Anginoni, M., Pizzolatti, M. G., Santos, A. R. S., \& Marques, M. C. A. (2008). Inhibition of $\mathrm{H}^{+} / \mathrm{K}^{+}$ATPase in the gastroprotective effect of Baccharis illinita DC. Journal of Pharmacy and Pharmacology, 60(8), 1105-1110.

Heinrich, G., Pfeifhofer, H. W., Stabentheiner, E., \& Sawidis, T. (2002). Glandular hairs of Sigesbeckia jorullensis Kunth (Asteraceae): morphology, histochemistry and composition of essential oil. Annals of Botany, 89(4), 459-469.

Jasinski, V. C. G., Silva, R. Z., Pontarolo, R., Budel, J. M., \& Campos, F. R. (2014). Morpho-anatomical characteristics of Baccharis glaziovii in support of its pharmacobotany. Revista Brasileira de Farmacognosia, 24(6), 609-515.

Johansen, D. A. (1940). Plant microtechnique. New York, London: MacGraw-Hill Book Company.

Lago, J. H. G., Romoff, P., Fávero, O. A., Soares, M. G., Baraldi, P. T., Corrêa, A. G., \& Souza, F. O. (2008). Composicão química dos óleos essenciais de seis espécies do gênero Baccharis de "Campos de Altitude" da Mata Atlântica Paulista. Química Nova, 31(4), 727-730.

Lersten, N. R., Czlapinski, A. R., Curtis, J. D., Freckmann, R., \& Horner, H. T. (2006). Oil bodies in leaf mesophyll cells of angiosperms: overview and selected survey. American Journal of Botany, 93(12), 1731-1739.

Meric, C., \& Dane, F. (2004). Calcium oxalate crystals in floral organs of Helianthus annuus L. and H. tuberosus L. (Asteraceae). Acta Biologica Szegediensis, 48, 19-23.

Müller, J. (2013). World checklist of Baccharis L. (Compositae-Astereae), version 2013-09-03. Herbarium Haussknecht, Friedrich-SchillerUniversität, Jena, $170 \mathrm{pp}$.
O'Brien, T. P., Feder, N., \& McCully, M. E. (1964). Polychromatic staining of plant cell walls by toluidine blue O. Protoplasma, 59(2), 368-373.

Pagni, A. M., \& Masini, A. (1999). Morphology, distribution and histochemistry of secretory structures in vegetative organs of Santolina leucantha Bertol. (Asteraceae). Israel Journal of Plant Sciences, 47(4), 257-263.

Pereira, C. B., Farago, P. V., Budel, J. M., Paula, J. P., Folquitto, D. G. Miguel, O. G., \& Miguel, M. D. (2014). New contribution to the pharmacognostic study of carquejas: Baccharis milleflora DC., Asteraceae. Latin American Journal of Pharmacy, 33, 841-847.

Pereira, C. B., Kanunfre, C. C., Farago, P. V., Borsato, D. M., Budel, J. M., Maia, B. H. L. N. S. M., ... Miguel, O. G. (2017). Cytotoxic mechanism of Baccharis milleflora (Less.) DC. essential oil. Toxicology in Vitro, 42, 214-221.

Perez, C., \& Anesini, C. (1993). Screening of plants used in Argentine folk medicine for antimicrobial activity. Journal of Ethnopharmacology 39(2), 119-128.

Perez, C., \& Anesini, C. (1994). Inhibition of Pseudomonas aeruginosa by argentinean medicinal plants. Fitoterapia, 65, 169-172.

Rodriguez, M. V., Gattuso, S. J., \& Gattuso, M. A. (2013). Micrographic standarization of Baccharis L. species (Asteraceae). Dominguezia, 29, 39-54

Sass, J. E. (1951). Botanical microtechnique (2nd ed.). Ames, lowa: State College Press.

Schossler, P., Schneider, G. L., Wunsch, D., Soares, G. L. G., \& Zini, C. A (2009). Volatile compounds of Baccharis punctulata, Baccharis dracunculifolia and Eupatorium laevigatum obtained using solid phase microextraction and hydrodistillation. Journal of the Brazilian Chemical Society, 20(2), 277-287.

Sheikh, N. A., Desai, T. R., \& Patel, R. D. (2016). Pharmacognostic Evaluation of Melilotus officinalis Linn. Pharmacognosy Journal, 8(3), 239-242.

Soares, V. C. G., Bristot, D., Pires, C. L., Toyama, M. H., Romoff, P., Pena, M. J., ... Toyama, D. O. (2012). Evaluation of extracts and partitions from aerial parts of Baccharis microdonta on enzymatic activity, pro-inflammatory and myotoxic activities induced by secretory phospholipase A2 from Bothrops jararacussu. Toxicon, 60(2), 208.

Souza, C. A., Farago, P. V., Duarte, M. R., \& Budel, J. M. (2011). Pharmacobotanical study of Baccharis singularis (Vell.) G.M. Barroso, Asteraceae. Latin American Journal of Pharmacy, 30, 311-317.

Tischer, B., Vendruscolo, R. G., Wagner, R., Menezes, C. R., Barin, C. S. Giacomelli, S. R., ... Barin, J. S. (2017). Effect of grinding method on the analysis of essential oil from Baccharis articulata (Lam.) Pers. Chemical Papers, 71(4), 753-761.

How to cite this article: Budel JM, Raman V, Monteiro LM et al. Foliar anatomy and microscopy of six Brazilian species of Baccharis (Asteraceae). Microsc Res Tech. 2018;00:1-11. https:// doi.org/10.1002/jemt.23045 